\title{
Transcriptional Regulator ERG
}

National Cancer Institute

\section{Source}

National Cancer Institute. Transcriptional Regulator ERG. NCI Thesaurus. Code C18557.

Transcriptional regulator ERG (486 aa, $\sim 55 \mathrm{kDa}$ ) is encoded by the human ERG gene. This protein plays a role in protein-protein interactions and transcriptional regulation. 